\title{
Author Correction: Declines in mental health associated with air pollution and temperature variability in China
}

\author{
Tao Xue ${ }^{1}$, Tong Zhu', Yixuan Zheng ${ }^{2} \&$ Qiang Zhang ${ }^{2}$
}

Correction to: Nature Communications https://doi.org/10.1038/s41467-019-10196-y, published online 15 May 2019.

The original version of the Supplementary Information associated with this Article contained confidential geographical information in Supplementary Figs. 1 and 2. The HTML has been updated to include a corrected version of these figures. In corrected Supplementary Fig. 1, locations have been randomly placed within a $50 \mathrm{~km}$ radius of the surveyed sites and survey locations have been removed from Supplementary Fig. 2.

Published online: 06 August 2019

(c) Open Access This article is licensed under a Creative Commons Attribution 4.0 International License, which permits use, sharing, adaptation, distribution and reproduction in any medium or format, as long as you give appropriate credit to the original author(s) and the source, provide a link to the Creative Commons license, and indicate if changes were made. The images or other third party material in this article are included in the article's Creative Commons license, unless indicated otherwise in a credit line to the material. If material is not included in the article's Creative Commons license and your intended use is not permitted by statutory regulation or exceeds the permitted use, you will need to obtain permission directly from the copyright holder. To view a copy of this license, visit http://creativecommons.org/licenses/by/4.0/.

(c) The Author(s) 2019

\footnotetext{
${ }^{1}$ BIC-ESAT and SKL-ESPC, College of Environmental Science and Engineering, Peking University, Beijing 100871, China. ${ }^{2}$ Ministry of Education Key Laboratory for Earth System Modeling, Department of Earth System Science, Tsinghua University, Beijing 100084, China. Correspondence and requests for materials should be addressed to T.Z. (email: tzhu@pku.edu.cn)
} 